\title{
Infections of Cryptocaryon irritans on wild fish from southeast Queensland, Australia
}

\author{
B. K. Diggles, R. J. G. Lester* \\ Department of Parasitology, The University of Queensland, Brisbane, Queensland 4072, Australia
}

\begin{abstract}
Wild-caught marine fish from 3 sites in SE Queensland, Australia, were examined over a period of up to $13 \mathrm{mo}$ for infections of the parasitic ciliate Cryptocaryon irritans. Infections of $C$. irritans were found to be common on the fish sampled. Out of a total of 358 fish (14 species), 239 (66.7\%) from 13 species were found to be infected. At Site 1 at the mouth of an estuary, the prevalence of $C$. irritans infections was $79 \%$ and the mean intensity was 12.9 parasites fish ${ }^{-1}$. At Site 2, a coastal bar area, the prevalence of infection dropped to $66 \%$ and a mean intensity of 5.0 parasites fish ${ }^{-1}$, whilst at Site 3 on the Great Barrier Reef, prevalence was lowest at $51 \%$ with a mean intensity of 2.3 parasites fish ${ }^{-1}$ The study concentrated on 2 sparid fishes, Acanthopagrus australis from Sites 1 and 2 and Gymnocranius audleyi from Site 3 . The prevalence of infections on $A$. australis from Site $1(\mathrm{n}=101)$ was $100 \%$ with a mean intensity of 14.6 parasites fish ${ }^{-1}$, whilst at Site $2(n=74)$ the prevalence was $88 \%$ at a mean intensity of 5.2 parasites fish ${ }^{-1}$. There was no apparent seasonality in prevalence or intensity of infections at Sites 1 and 2 despite water temperatures ranging between 15 and $27^{\circ} \mathrm{C}$. At Site 3 , the prevalence of infections of $G$. audleyi $(n=39)$ was $38 \%$ with a mean intensity of 1.9 parasites fish ${ }^{-1}$. The diameter of the tomonts collected from $A$. australis from Sites 1 and 2 varied inversely with water temperature, and was not related to host size. Our results show that infections of $C$. iritans are common on wild fish, not rare as previously thought. This may be partially due to the increased sensitivity of our tomont collection technique. Our data suggest that $C$. irritans may exhibit a degree of host specificity in the wild, and also that its natural distribution can be extended into estuaries and seasonally into warm temperate waters.
\end{abstract}

KEY WORDS: Cryptocaryon irritans - Prevalence - Intensity - Wild infections - SE Queensland . Australia $\cdot$ Acanthopagrus australis · Gymnocranius audleyi

\section{INTRODUCTION}

Cryptocaryon irritans Brown, 1951 is the parasitic ciliate that causes 'whitespot' disease of marine fish. It is responsible for severe epizootics resulting in major stock losses in both aquarium fishes (Brown 1951, Sikama 1961, Nigrelli \& Ruggieri 1966, Wilkie \& Gordin 1969) and mariculture facilities worldwide (Huff \& Burns 1981, Colorni 1985, Kaige \& Miyazaki 1985, Rasheed 1989, Diamant et al. 1991). C. irritans has a direct lifecycle which is completed most effectively when fish are confined. The histophagous trophont feeds on the epidermis of the skin and gills of the fish. After a period of time the trophont leaves the fish and

·E-mail: r.lester@mailbox.uq.oz.au sinks to the substrate, where it forms a cyst or 'tomont'. The tomont undergoes a series of palintomic divisions producing daughter cells or 'tomites' which differentiate into 'theronts'. Upon excystment the theronts are liberated to infect new hosts. On average the whole life cycle is completed in around 9 to $10 \mathrm{~d}$ at 24 to $25^{\circ} \mathrm{C}$ (Colorni 1987).

Previous studies of Cryptocaryon irritans have largely been confined to the examination of infections of captive fish after the parasite has been introduced into aquaria or a mariculture facility, often by an unknown source. Indeed, the presence of $C$. irritans is usually detected only after its numbers have built up on confined fish, and the original source of infection in these cases is often a matter of speculation. Previous records from wild fish indicate that natural infections 
of C. irritans are geographically widespread, but rare. One study of 36 species of coral reef fish from Fiji (Laird 1956) found infections of C. irritans on only 1 species (Epinephelus merra). Wilkie \& Gordin (1969) found C. irritans infections on wild opaleye Girella nigricans from tidal pools near Scripps Institute of Oceanography, California, USA, but indicated that these infections may have been introduced by aquarium effluent from the Institute. In Malaysia, Leong \& Wong (1989) found the prevalence of infections of $C$. irritans on wild Lutjanus johni to be only $2 \%$ (1 fish out of 50 infected). Bunkley-Williams \& Williams (1994) recorded 3 specimens of sand drum Umbrina coroides from Puerto Rico as heavily infected with $C$. irritans, whilst 48 specimens of 27 other species examined from the same collections were not infected. Other than $U$. coroides, these authors had not recorded $C$. irritans from over 3000 specimens of over 250 species of wild fish collected in 20 yr of sampling. Recent laboratory studies of $C$. irritans have obtained the parasite from retailers importing various species of tropical marine fish (Burgess \& Matthews 1994a, 1995, Yoshinaga \& Dickerson 1994).

Our interest in Cryptocaryon irritans stems from our observations that when wild yellow-fin bream Acanthopagrus australis from the Brisbane River, Moreton Bay, Queensland, Australia, were maintained in recirculating aquaria, they became infected with $C$. irritans and the infection quickly reached epizootic levels at $20 \pm 1^{\circ} \mathrm{C}$ and $35 \%$ salinity. Since the water tempera-

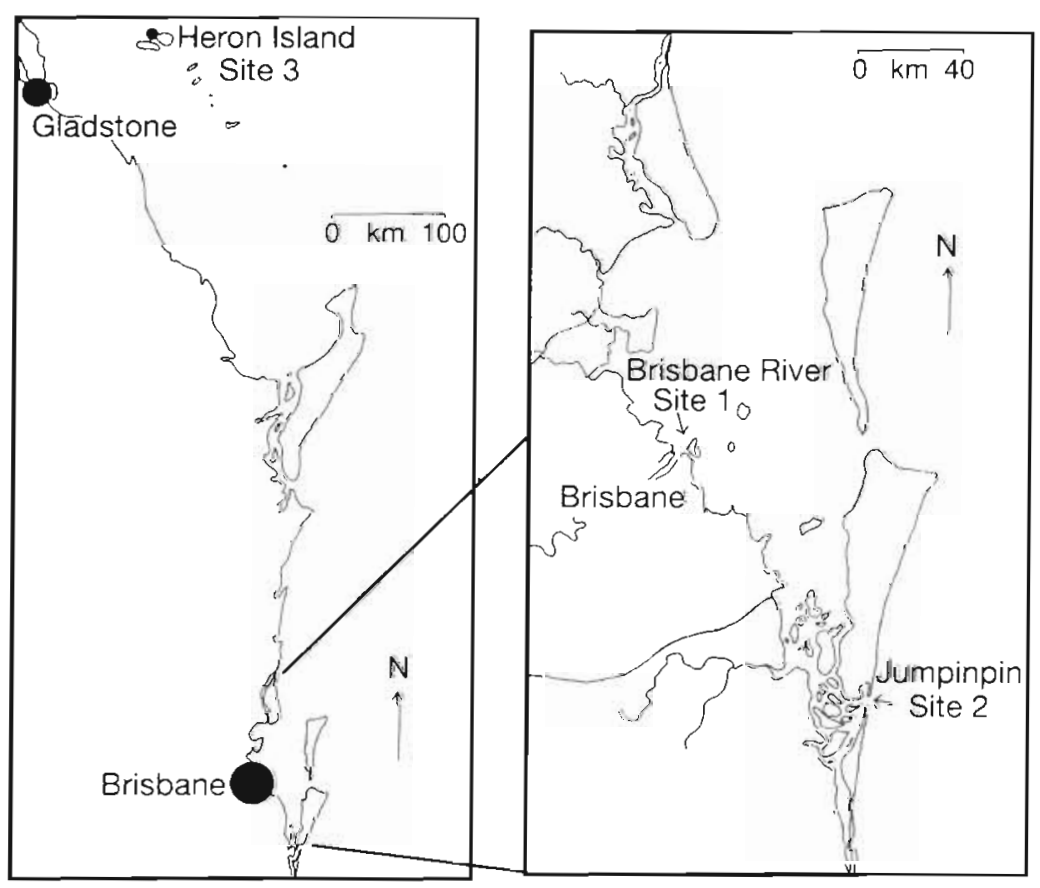

Fig. 1. Location of study sites in southeast Queensland, Australia ture in Moreton Bay and its estuaries ranges annually between 15 and $28^{\circ} \mathrm{C}$, and C. irritans is regarded as a parasite of mainly tropical fishes (Wilkie \& Gordin 1969), we decided to conduct a survey of wild A. australis to examine whether $C$. irritans infections occurred throughout the year or whether there were seasonal variations. As the survey progressed, other sampling sites and fish species were added to determine whether the prevalence and intensity of infections varied between fish species and study sites.

\section{MATERIALS AND METHODS}

Fish were collected by line fishing or cast net at 3 sampling sites between March 1994 and May 1995. Site 1 was at the mouth of the Brisbane River estuary in western Moreton Bay, SE Queensland (Fig. 1). Site 2 was Jumpinpin, a coastal bar area in eastern Moreton Bay, whilst Site 3 was Heron Island $\left(23^{\circ} 27^{\prime} \mathrm{S}\right.$, $\left.151^{\circ} 55^{\prime} \mathrm{E}\right)$, a coral cay in the southern Great Barrier Reef approximately $700 \mathrm{~km}$ north of Moreton Bay. A total of 152 fish of 6 species were collected from Site 1 in 10 sampling trips from March 1994 to April 1995. During this time water temperature at the site ranged between 15 and $27^{\circ} \mathrm{C}$ and salinity between 35 and $36 \%$, except for 1 sampling trip (March 1994) where the salinity was $30 \%$. The species collected were Acanthopagrus australis (Günther), Rhabdosargus sarba (Forsskål), Gerres ovatus Günther, Sillago maculata Quoy \& Gaimard, Spheroides hamiltoni (Gray \& Richardson), and Lutjanus russelli (Bleeker). A total of 130 fish from 8 species were collected from Site 2 in 8 sampling trips from May 1994 to May 1995. During this time water temperature at the site ranged between 16 and $27^{\circ} \mathrm{C}$ and salinity between 35 and $36 \%$. The species collected from Site 2 included $A$. australis, $R$. sarba, $G$. ovatus, $S$. maculata, Sillago ciliata Cuvier, $S$. hamiltoni, Spheroides pleurogramma (Regan) and Pagrus auratus (Bloch \& Schneider). Fish from Sites 1 and 2 were identified using Grant (1985).

All fish from Sites 1 and 2 were transported back to the laboratory in aerated 601 plastic bins containing seawater from the site of collection. Within 2 to 6 h of capture, fish were placed individually in aquaria containing seawater diluted to $30 \%$ with tap water (except for the 9 specimens of Spheroides pleurogramma which were all placed in 1 aquarium). Small fish less than $18 \mathrm{~cm}$ fork length 
were placed in $22 \times 22 \times 45 \mathrm{~cm}$ aquaria filled with approximately $12 \mathrm{l}$ of seawater, whilst larger fish up to $30 \mathrm{~cm}$ fork length were placed in $30 \times 30 \times 60 \mathrm{~cm}$ aquaria in approximately $25 \mathrm{l}$ of seawater. Fish were held in aquaria for $8 \mathrm{~d}$ at 22 to $23^{\circ} \mathrm{C}$ and the bottom of each aquarium was examined for $C$. irritans tomonts twice, after 4 and $8 \mathrm{~d}$. These time periods prevented auto-infection, as preliminary studies showed that $C$. irritans tomonts from Acanthopagrus australis take at least $5 \mathrm{~d}$ to excyst at 22 to $23^{\circ} \mathrm{C}$. Preliminary studies also showed that all trophonts left specimens of $A$. australis prior to Day 8 post infection at 22 to $23^{\circ} \mathrm{C}$ and encysted as tomonts which could be located on the tank bottom

No filtration was used throughout the $8 \mathrm{~d}$ period, with water quality being maintained by aeration, a $1 / 3$ water change on Day 2, and transferring fish to clean aquaria containing unused $30 \%$ seawater on Day 4 . The fish were not fed for the duration of the experiments to help maintain water quality and minimise the production of excessive amounts of sediment.

To examine the aquarium bottom the fish was removed, measured (length to caudal fork in $\mathrm{cm}$ ) and then transferred to a clean aquarium. The sediment in each aquarium was then allowed to settle for $5 \mathrm{~min}$ before the supernatant water was siphoned off, with care being taken not to disturb any sediment on the tank bottom, until approximately 1 to $2 \mathrm{~cm}$ of water remained. The aquarium was then placed on a background of black plastic and the entire bottom was examined for tomonts which had adhered to the glass surface. Stationary tomonts were easily seen with the naked eye against the black background when the surrounding sediment was moved away using a water jet from a pasteur pipette. The tomonts detected using this method were carefully detached using a fine paintbrush, collected with a pipette, counted and their diameters were measured. The aquarium bottom was then thoroughly brushed with a large paintbrush to remove any remaining unseen or unattached tomonts, after which the sediment was transferred to a 31 beaker to settle for $5 \mathrm{~min}$ before decanting of the supernatant. The concentrated sediment was then transferred to a large petri dish and examined under a dissecting microscope, where any remaining tomonts were collected, counted and measured. All measurements of tomont diameters were made using a calibrated ocular micrometer. Performing these examinations twice for each fish, on Days 4 and 8 of captivity, it was possible to record the number and diameter of all of the tomonts which left each fish.

Surveys at Site 3 were conducted in a slightly different manner. A total of 76 fish from 5 species were collected at Site 3 in 2 sampling trips. Specimens of Gymnocranius audleyi Ogilby and Lethrinus miniatus
(Bloch \& Schneider) were collected in October 1994, whilst these and specimens of Epinephelus quoyanus (Valenciennes), Lutjanus carponotatus (Richardson) and Plectropomus leopardus (Lacepède) were also collected from the same area in February 1995. Fish were transported to the laboratory in $60 \mathrm{l}$ plastic drums containing aerated seawater from the site of collection, then placed individually in aquaria. Aquarium sizes were as described above except for fish longer than $40 \mathrm{~cm}$ fork length, which were placed individually in aquaria measuring approximately $45 \times 45 \times 80 \mathrm{~cm}$. Water quality was maintained by directing a trickle of seawater into the aquaria so that the volume of seawater contained in the aquarium was exchanged about once daily. Water temperature was maintained at that of the sea water surrounding Heron Island at the time of experiments, $23^{\circ} \mathrm{C}$ for October 1994 and $28^{\circ} \mathrm{C}$ for January 1995, whilst salinity remained between 35 and $36 \%$ throughout. Procedures for feeding fish, examining aquarium bottoms and counting tomonts were as described for Sites 1 and 2. Fish from Site 3 were identified from Randall et al. (1990)

One- and 2-way ANOVA and Tukey's test were used to determine significant differences in tomont sizes between species and sampling sites. These and calculations of values for Pearson's correlation coefficient and linear regressions were performed on SAS software (Ver. 6.02 ). Probability values of less than 0.05 were considered significant.

\section{RESULTS}

A total of 358 fish of 14 species were collected from the 3 sites. Of these, tomonts of Cryptocaryon irritans were recorded from 239 fish $(66.7 \%$ ) from 13 species (Table 1 ).

At Site 1 the prevalence of Cryptocaryon irritans infections ranged between 0 and $100 \%$ for the 6 species examined. Overall, the prevalence of $C$. irritans infections at Site 1 was $79 \%$ (120 out of 152 fish), and the mean intensity was 12.9 tomonts fish ${ }^{-1}$ (1547 tomonts collected from 120 infected fish). The mean intensity of infections of Acanthopagrus australis (14.6 tomonts fish $^{-1}$ ) was much higher than that for all other species at Site 1 . The diameter of the tomonts collected varied significantly between species $(p=0.0001)$. The tomonts collected from $A$. australis (mean diameter $464 \mu \mathrm{m}$ ) were significantly larger than those from Rhabdosargus sarba (mean $370 \mu \mathrm{m}$ ) and Sillago maculata (mean $330 \mu \mathrm{m})$, but were not significantly different to the diameter of tomonts collected from Spheroides hamiltoni (mean $427 \mu \mathrm{m}$ ) or Lutjanus russelli (mean $486 \mu \mathrm{m})$. The mean diameter of the tomonts collected from all fish from Site $1(\mathrm{n}=1547)$ was $458 \mu \mathrm{m}$ (range: $210-763 \mu \mathrm{m})$. 
Table 1. Summary of data from 358 wild fish collected from 3 sites and examined for infections of Cryptocaryon irritans. n: num-

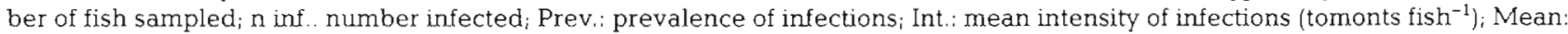
mean diameter of tomonts; Temp: water temperature at time of collection. 'Data from 9 specimens of $S$. pleurogramma not included

\begin{tabular}{|c|c|c|c|c|c|c|c|c|c|c|c|c|c|c|c|c|c|c|}
\hline \multirow[t]{2}{*}{ Species } & \multicolumn{6}{|c|}{ _- Site 1, Brisbane River } & \multicolumn{6}{|c|}{ - Site 2, Jumpinpin } & \multicolumn{6}{|c|}{ _Site 3, Heron Island } \\
\hline & $\mathrm{n}$ & $\begin{array}{c}\mathrm{n} \\
\text { inf. }\end{array}$ & $\begin{array}{c}\text { Prev. } \\
(\%)\end{array}$ & Int. & $\begin{array}{l}\text { Mean } \\
(\mu \mathrm{m})\end{array}$ & $\begin{array}{l}\text { Temp } \\
\left({ }^{\circ} \mathrm{C}\right)\end{array}$ & $\mathrm{n}$ & $\begin{array}{c}\mathrm{n} \\
\text { inf. }\end{array}$ & $\begin{array}{l}\text { Prev. } \\
(\%)\end{array}$ & Int. & $\begin{array}{l}\text { Mean } \\
(\mu \mathrm{m})\end{array}$ & $\begin{array}{l}\text { Temp } \\
\left({ }^{\circ} \mathrm{C}\right)\end{array}$ & $\mathrm{n}$ & $\begin{array}{c}\mathrm{n} \\
\text { inf. }\end{array}$ & $\begin{array}{c}\text { Prev. } \\
(\%)\end{array}$ & Int. & $\begin{array}{l}\text { Mean } \\
(\mu \mathrm{m})\end{array}$ & $\begin{array}{l}\text { Temp } \\
\left({ }^{\circ} \mathrm{C}\right)\end{array}$ \\
\hline $\begin{array}{l}\text { Acanthopagrus } \\
\text { australis }\end{array}$ & 101 & 101 & 100 & 14.6 & 464 & $15-27$ & 74 & 65 & 88 & 5.2 & 487 & $16-27$ & - & - & - & - & - & - \\
\hline $\begin{array}{l}\text { Rhabdosargus } \\
\text { sarba }\end{array}$ & 14 & 7 & 50 & 2 & 370 & $15-23$ & 11 & 3 & 27 & 2.6 & 365 & $25-26$ & - & - & - & - & - & - \\
\hline $\begin{array}{l}\text { Gerres } \\
\text { ovatus }\end{array}$ & 16 & 0 & 0 & - & - & $15-27$ & 9 & 1 & 11 & 1 & 412 & 23 & - & - & - & - & - & - \\
\hline $\begin{array}{l}\text { Sillago } \\
\text { maculata }\end{array}$ & 7 & 7 & 100 & 7.6 & 330 & $19-27$ & 9 & 2 & 22 & 8 & 329 & $23-26$ & - & - & - & - & - & - \\
\hline $\begin{array}{l}\text { Sillago } \\
\text { ciliata }\end{array}$ & - & - & - & - & - & - & 16 & 8 & 50 & 5.7 & 328 & $20-26$ & - & - & - & - & - & - \\
\hline $\begin{array}{l}\text { Spheroides } \\
\text { hamiltoni }\end{array}$ & 9 & 3 & 33 & i. 3 & 427 & $23-27$ & 1 & 1 & 100 & 2 & 355 & 23 & - & - & - & - & - & - \\
\hline $\begin{array}{l}\text { Spheroides } \\
\text { pleurogramma }\end{array}$ & - & - & - & - & - & - & 9 & ? & $?$ & 3.3 & 383 & 23 & - & - & - & - & - & - \\
\hline $\begin{array}{l}\text { Lutjanus } \\
\text { russelli }\end{array}$ & 5 & 2 & 40 & 1 & 486 & $23-25$ & - & - & - & - & - & - & - & - & - & - & - & - \\
\hline $\begin{array}{l}\text { Pagrus } \\
\text { auratus }\end{array}$ & - & - & - & - & - & - & 1 & 0 & 0 & - & - & 25 & - & - & - & - & - & - \\
\hline $\begin{array}{l}\text { Gymnocranius } \\
\text { audleyi }\end{array}$ & - & - & - & - & - & - & - & - & - & - & - & - & 39 & 15 & 38 & 1.9 & 318 & $23-28$ \\
\hline $\begin{array}{l}\text { Lethrinus } \\
\text { miniatus }\end{array}$ & - & - & - & - & - & - & - & - & - & - & - & - & 15 & 11 & 73 & 3.9 & 313 & $23-28$ \\
\hline $\begin{array}{l}\text { Plectropomus } \\
\text { leopardus }\end{array}$ & - & - & - & - & - & - & - & - & - & - & - & - & 1 & 1 & 100 & 2 & 348 & 28 \\
\hline $\begin{array}{l}\text { Epinephelus } \\
\text { quoyanus }\end{array}$ & - & - & - & - & - & - & - & - & - & - & - & - & 7 & 4 & 57 & 2 & 357 & 28 \\
\hline $\begin{array}{l}\text { Lutjanus } \\
\text { carponotatus }\end{array}$ & - & - & - & - & - & - & - & - & - & - & - & - & 14 & 8 & 57 & 1.2 & 331 & 28 \\
\hline Total & 152 & 120 & 79 & 12.9 & 458 & $15-27$ & 130 & $80^{\circ}$ & $66^{\circ}$ & 5.0 & 457 & $16-27$ & 76 & 39 & 51 & 2.3 & 322 & $23-28$ \\
\hline
\end{tabular}

At Site 2 the prevalence of infections ranged between 11 and $88 \%$ for the 5 species of which more than 1 specimen was examined (Table 1). In addition, 1 specimen of Spheroides hamiltoni was infected and 1 specimen of $P a-$ grus auratus was uninfected. Data for prevalence were not gathered for the 9 specimens of $S$. pleurogramma. Overall the prevalence of infections at Site 2 (excluding S. pleurogramma) was $66 \%$ ( 80 out of $121 \mathrm{fish}$ ) and the intensity of infections (including S. pleurogramma where 30 cysts were collected from the aquarium containing 9 fish) averaged 5 tomonts fish $^{-1}$ (443 tomonts collected from 89 fish). Specimens of Sillago maculata ( 8 tomonts fish $\left.^{-1}\right)$, Sillago ciliata (5.7 tomonts fish $^{-1}$ ) and Acanthopagrus australis (5.2 tomonts $\mathrm{fish}^{-1}$ ) had the highest mean intensities of infection at Site 2. Again, the diameter of tomonts varied significantly between species $(\mathrm{p}=$ 0.0001 ), with tomonts collected from $A$. australis (mean $487 \mu \mathrm{m}$ ) being significantly larger than those collected from all other species from Site 2 . The mean diameter of the tomonts collected from fish from Site 2 ( $n=443$, mean $457 \mu \mathrm{m}$, range: $197-684 \mu \mathrm{m}$ ) was virtually identical to that from Site 1.
At Site 3 the prevalence of infections of Cryptocaryon irntans ranged between 38 and $73 \%$ for the 4 species of which more than 1 specimen was examined (Table 1). In addition, the 1 specimen of Plectropomus leopardus examined was found to be infected. Overall the prevalence of $C$. irritans infections at Site 3 was lowest at $51 \%$ (39 out of 76 fish), as was the mean intensity (2.35 tomonts fish $^{-1}$ ). Specimens of Lethrinus miniatus had the highest mean intensity of infection (3.9 tomonts fish $^{-1}$ ). The diameter of the tomonts collected from fish from Site 3 did not vary significantly between species, however overall their diameter $(n=92$, mean $=322 \mu \mathrm{m}$, range: $221-505 \mu \mathrm{m})$ was significantly smaller $(\mathrm{p}=$ $0.0001)$ than that of the tomonts collected from both Sites 1 and 2.

Closer examination of infections of the 175 specimens of Acanthopagrus australis collected from Sites 1 and 2 showed that there was no evidence that the prevalence or intensity of Cryptocaryon irritans infections varied seasonally with water temperature (Fig. 2). Infections were recorded throughout the year even though water temperatures remained at or below $19^{\circ} \mathrm{C}$ for around $4 \mathrm{mo}$ 


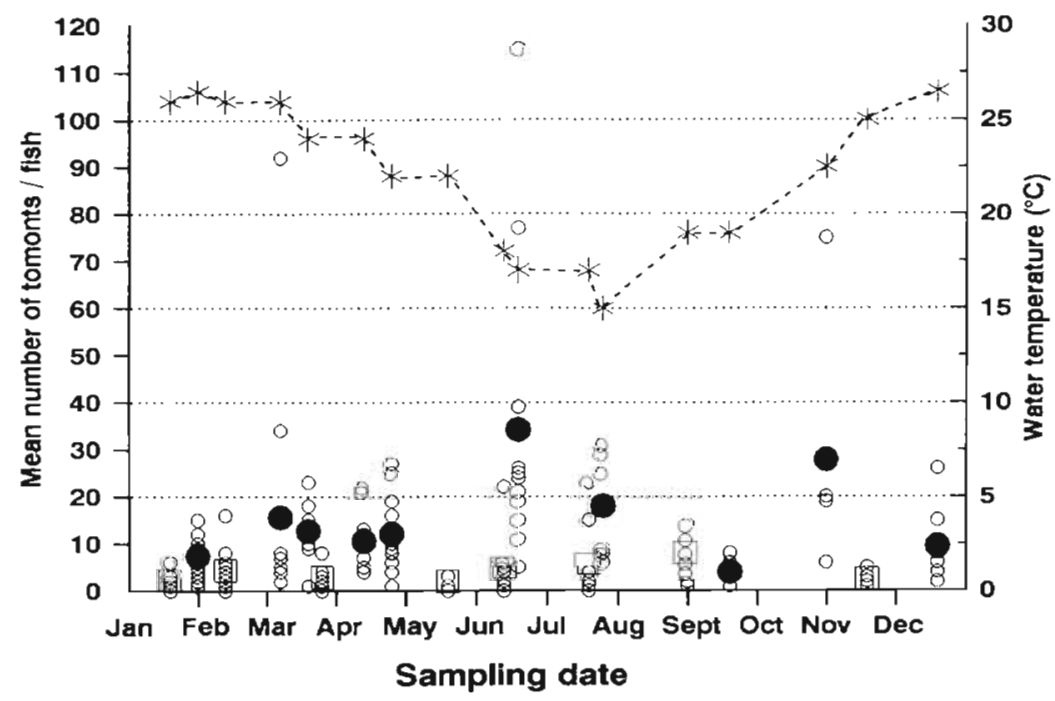

Fig. 2. Mean intensity of infections of Cryptocaryon irritans found on Acanthopagrus australis collected from 10 samples from Site $1(\mathrm{n}=101$ fish, mean length $15.6 \mathrm{~cm})$, and 8 samples from Site $2(\mathrm{n}=74 \mathrm{fish}$, mean length $16.2 \mathrm{~cm})$. Collections were taken over a period of 13 and 12 months respectively. Water temperatures $(-*-)$ ranged between 15 and $27^{\circ} \mathrm{C}$. (O) Number of tomonts from individual fish,

(-) mean per sample at Site $1,(\square)$ mean per sample at Site 2
1 and 2 were recorded for each sample to examine whether tomont diameter varied with water temperature at the collection site. The results show that as water temperature at the collection site decreased, tomont diameter increased (Fig. 6). Strong negative linear correlations were found between the mean tomont diameter for each sample and the water temperature at the time of collection (Pearson correlation coefficient for Site 1, $r=-0.85, n=10$, for Site 2, $r=-0.78, n=8$ ) (Fig. 7).

\section{DISCUSSION}

The prevalence and intensity of infections of Cryptocaryon irritans varied among fish species within a sampling site. At Site 1, Acanthopagrus australis and Sillago maculata harboured the heaviest infections at the highest prevalences, with tomonts

between June and mid-September and dropped to $15^{\circ} \mathrm{C}$ in August. The fish with the heaviest infection recorded in this study (115 tomonts) was collected from Site 1 in mid June (water temperature $17^{\circ} \mathrm{C}$ ), and the highest intensity of infection (mean 34.2 tomonts per fish, 11 fish collected) was also recorded in the same sample. It should be noted that most of the variation in the mean intensity of infections, especially for the June and November samples from Site 1, was due to the presence of a small number of heavily infected fish (Fig. 2). This is also shown in Fig. 3, which depicts the distribution of $C$. irritans infections of the A. australis sampled from both Sites 1 and 2 . The data conform to an over-dispersed distribution, with the majority of fish harbouring light infections.

A wide range of sizes of Acanthopagrus australis were sampled at both sites $(7$ to $26 \mathrm{~cm}$ fork length for Site 1,9 to $26 \mathrm{~cm}$ for Site 2). These size ranges cover $0+$ to $3+$ year class fish (Pollock 1982). When intensity of infections was compared to fish length, there was little correlation (Fig. 4). The diameter of the tomonts collected from each fish was also recorded and compared to fish length. It can be seen from these results that tomont diameter was not influenced by fish length over the size range sampled here (Fig. 5).

The diameter of the tomonts collected from Acanthopagrus australis from Sites from $A$. australis being significantly larger than those collected from $S$. maculata. Interestingly, none of the 16 specimens of Gerres ovatus from Site 1 were infected despite these fish being captured in many instances in the same net as specimens of A. australis and $S$. maculata. Similar results were obtained from Site 2, where $A$. australis had the highest prevalence of infections and the largest tomonts, S. maculata, $S$. ciliata and $A$. australis had the heaviest infections, and $G$. ovatus was lightly infected. At Site 3, Lethrinus miniatus had the highest prevalence and intensity of infec-

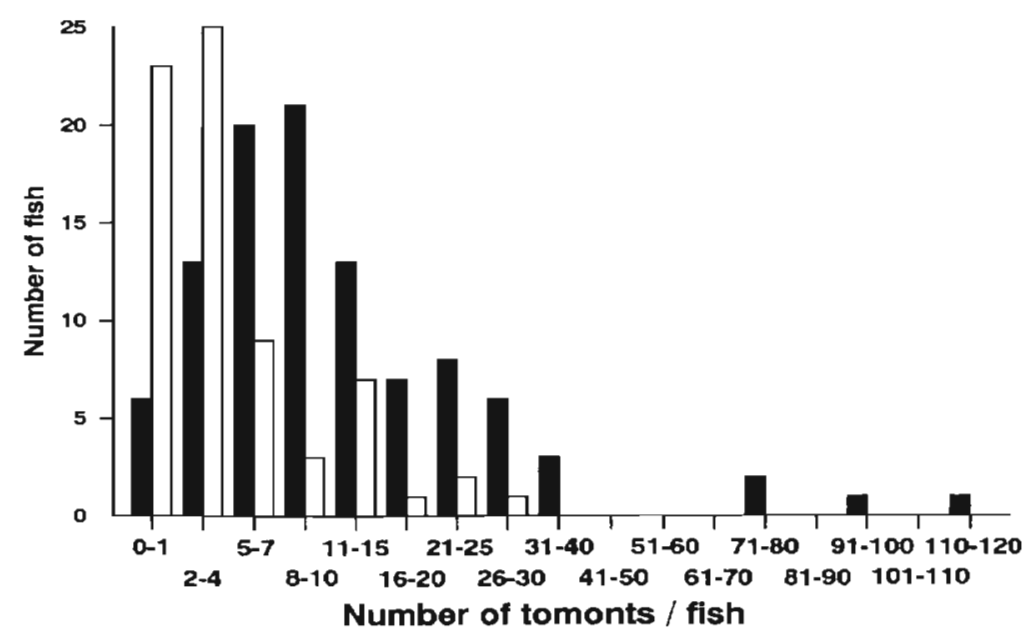

Fig. 3. Distribution of infections of Cryptocaryon irritans among specimens of Acanthopagrus australis collected from Sites 1 and 2. Most fish were lightly infected. (ם) Site 1, ( $\square$ ) Site 2 


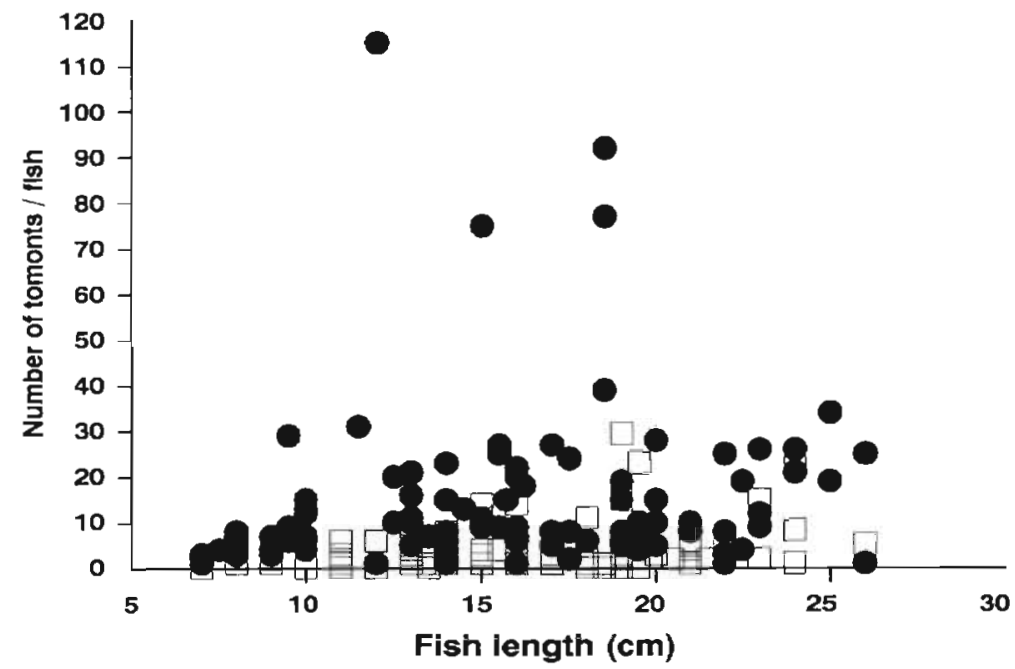

Fig. 4. Plot of fish length and the intensity of Cryptocaryon irritans infections for each Acanthopagrus austraiis coìected from Sites 1 and 2. Mean intensity was 14.6 tomonts fish ${ }^{-1}$ at Site 1 and 5.2 tomonts fish $^{-1}$ at Site 2 .

(ब) Site 1, (ㅁ) Site 2

tion of the species of which more than 1 specimen was examined.

These variations in host susceptibility to Cryptocaryon irritans are interesting as this parasite usually shows little host specificity on confined fish (Nigrelli \& Ruggieri 1966, Wilkie \& Gordin 1969, Burgess \& Matthews 1995). Differences in the susceptibility of wild hosts may be due to unequal exposure of hosts to infective stages because of differences in host behaviour or ecological niche. For example, foraging species with bottom feeding habits such as Acanthopagrus australis, Sillago maculata and $S$. cillata may be predisposed to infections of $C$. irritans because they inhabit shallow waters and are in close contact with the substrate (and tomonts) for long periods, often disturbing it during feeding. On the other hand, the discovery that excystment of $C$. irritans tomonts appears entrained to circadian Ihythms (Burgess \& Matthews 1994b, Yoshinaga \& Dickerson 1994), could indicate that $C$. irritans is adapted to infect fishes during periods of host inactivity, such as at night on coral reefs (Burgess \& Matthews 1994b). In this case inactive or territorial fishes may be more susceptible to infection.

Unequal exposure of potential hosts to infective stages of Cryptocaryon irritans could also be facilitated by a mechanism (presently hypothetical) whereby a chemical substance is exuded by a susceptible host species, such as Acan- thopagrus australis, and causes excystment of tomonts when the host is in close proximity. Since theronts of $C$. irritans are only viable for short periods of time (Burgess \& Matthews 1994a, Yoshinaga \& Dickerson 1994, Diggles \& Lester 1996), we hypothesise that it is selectively advantageous for mechanisms to develop which favour the release of infective stages when hosts are nearby. Chemicals from hosts, such as urea, stimulate hatching of larvae of various species of monogeneans (Kearn 1986). The oncomiracidia of monogeneans, like theronts of $C$. irritans, are ciliated infective stages with fish (and also elasmobranch) hosts. There is also some evidence that theronts of Ichthyophthirius multifiliis exhibit an attraction to chemical stimuli from fish serum (Lom \& Cerkasovová 1974).

It seems that some species of fish are particularly susceptible to Cryptocaryon irritans. These include, from this study Acanthopagrus australis, Sillago maculata and $S$. ciliata, from previous studies Hypsypops rubicunda (from Wilkie \& Gordin 1969), and in general sciaenids (Wilkie \& Gordin 1969, Bunkley-Williams \& Williams 1994), serranids (Wilkie \& Gordin 1969, Rasheed 1989) and sparids (Colorni 1985, Diamant et al. 1991). However, the low susceptibility of Rhabdosargus sarba in this study does show that even closely related fish from the same geographic areas (sparids $A$, australis and $R$. sarba from Sites 1 and 2) can differ markedly in their susceptibility to $C$. irritans.

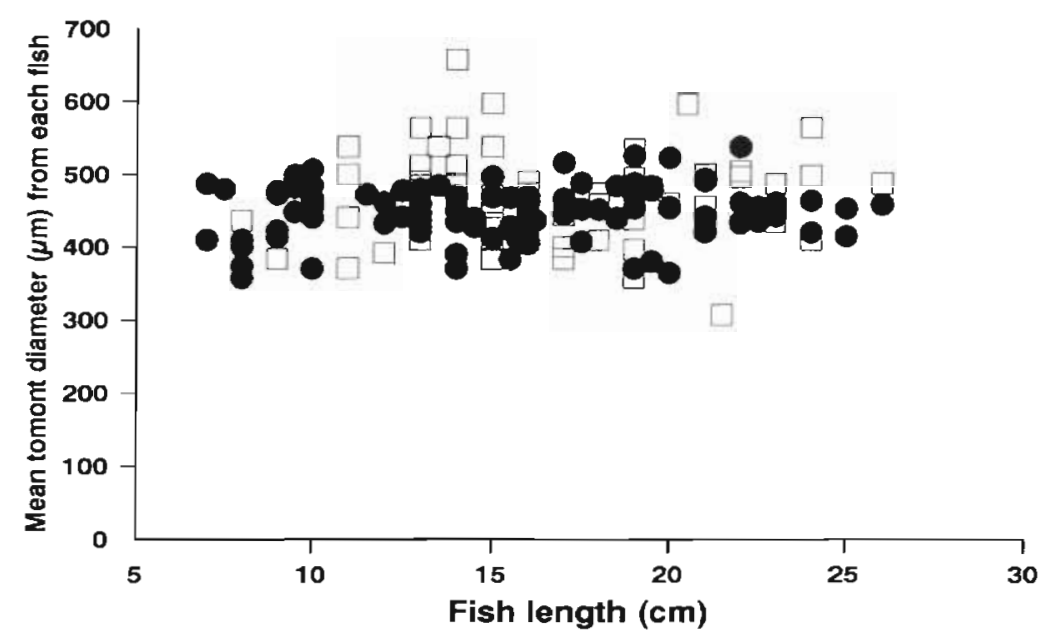

Fig. 5. Plot of fish length and the diameter of tomonts of Cryptocaryon irritans from each Acanthopagrus australis collected from Sites 1 and 2. Mean diameter of tomonts from fish from Site $1(\mathrm{n}=1474$ ) was $464 \mu \mathrm{m}$, whilst that from Site $2(n=338$ ) was 487 , $\mathrm{m}$. (@) Site 1, (口) Site 2 


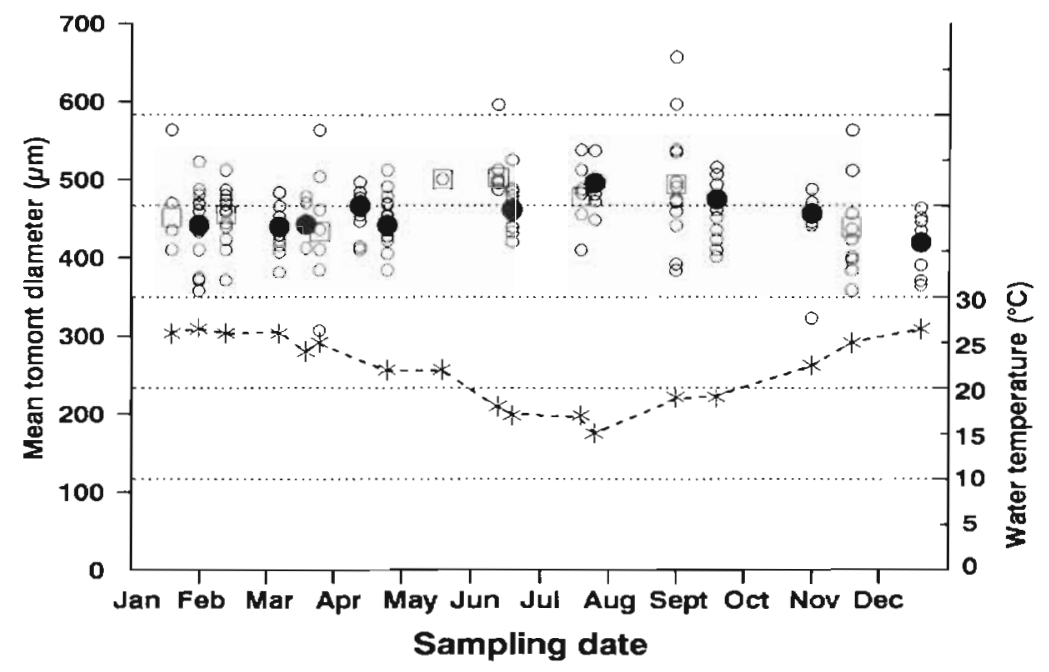

Fig. 6. Relationship between the mean diameter of tomonts of Cryptocaryon irritans collected from Acanthopagrus australis and water temperature (- $-*-$ - ) at the collection site over a period of 13 mo for Site 1 (10 samples) and 12 mo for Site 2 (8 samples). (0) Mean diameter of tomonts from individual fish,

(-) mean per sample at Site 1، (ㅁ) mean per sample at Site 2 sites in this survey could be related to many environmental factors. Obvious differences among sites included available substrates, the amount of water movement, water quality and the number of fish present, whilst salinity and water depth varied little among sites. The Brisbane River, where the highest prevalence and intensity of infections occurred, is the most sheltered of the 3 sites. This site is estuarine, with negligible wave action, moderate current flow and alternating rocky and muddy substrates. Water quality here is comparatively poor and total fish numbers (as indicated by our field collections) are comparatively low. Site 2 at Jumpinpin is a coastal bar location dominated by sandy substrates and predominantly strong currents. Water quality is good and fish numbers appear to be relatively high. Fish from Site 3 at Heron Island had the lowest prevalence and intensity

Non-susceptible fishes such as Gerres ovatus, which is also a bottom feeder (Blaber \& Blaber 1980), may come in contact with theronts but do not become infected, or perhaps conditions for trophont survival on such hosts are not optimal. The existence of fish resistant to Cryptocaryon irritans has been noted previously (Wilkie \& Gordin 1969), these include elasmobranchs, moray eels and teleosts which live in contact with the substrate such as gobies and flounders. However, Kaige \& Miyazaki (1985) have reported an epizootic of $C$. irritans in cultured Japanese flounder Paralichthys olivaceus. We have observed that specimens of leatherjacket Monocanthus chinensis (Osbeck) show no sign of infection with $C$. irritans even during epizootics which kill all other teleosts in our laboratory aquaria. It may be that in such cases a physical barrier to infection is present, or the fish become infected but the trophonts fail to subsequently grow. For example, laboratory studies of infections of C. irritans on Lates calcarifer (Bloch) and Macquaria novemaculeata (Steindachner) have shown that $C$. irritans infected both species but grew to a much larger size on $L$. calcarifer than on M. novemaculeata (Diggles \& Lester 1996).

The differences in the prevalence and intensities of infections among

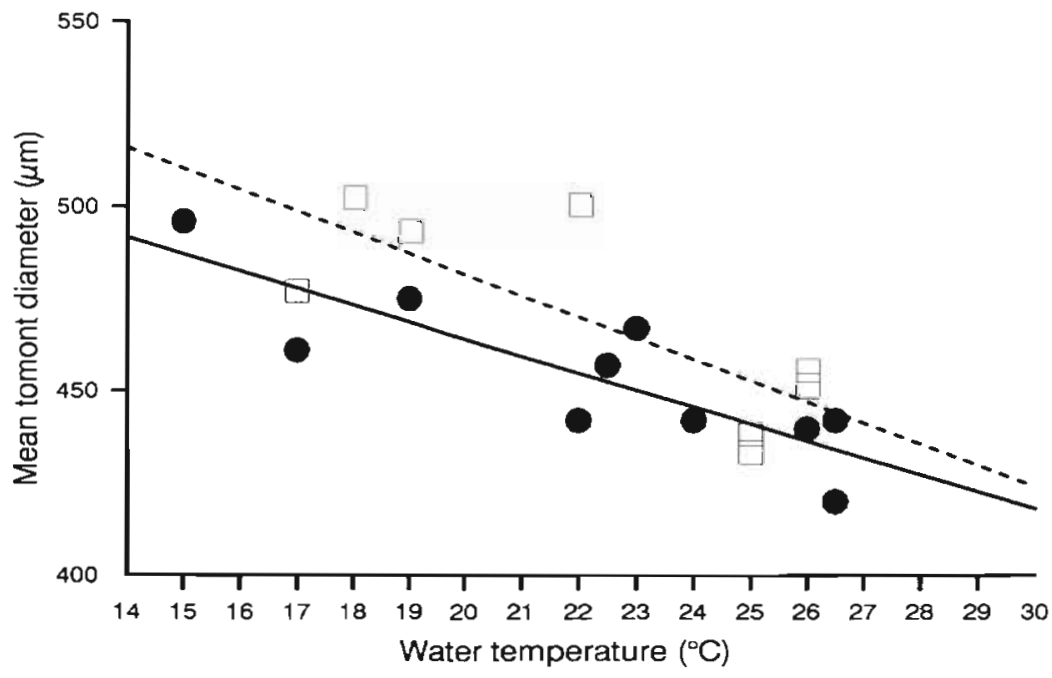

Fig. 7. Linear regressions depicting relationship between mean tomont diameter for each sample and water temperature at collection sites for tomonts of Cryptocaryon irritans collected from Acanthopagrus australis. For Site 1 (- - ) , $D=556-4.6 T\left(\mathrm{r}^{2}=0.73\right)$, for Site $2(--\square--), D=596.6-5.75 T\left(\mathrm{I}^{2}=0.60\right) . D=$ expected diameter of tomonts $(\mu \mathrm{m}), T=$ temperature $\left({ }^{\circ} \mathrm{C}\right)$ 
water movement, the number of fish present, water quality, or a combination of some or all of these factors.

Even though the water temperature at Sites 1 and 2 dropped below $19^{\circ} \mathrm{C}$ for around 4 mo of the year, infections of Cryptocaryon irritans on Acanthopagrus australis were present all year round. Indeed the heaviest infections at Site 1 occurred at $17^{\circ} \mathrm{C}$, and infections were still recorded at $15^{\circ} \mathrm{C}$, a temperature at which $\mathrm{C}$. irritans infections were found not to occur in previous studies (Wilkie \& Gordin 1969). In contrast, Cheung et al. (1979) found the optimal temperature for excystment of C. irritans to be $30^{\circ} \mathrm{C}$. This indicates the possible existence of strains of $C$. irritans which can be differentiated by their temperature tolerances, as has been proposed previously for $C$. irritans by Diamant et al. (1991), and for the freshwater ciliate Ich thyophthirius multifiliis Fouquet by Nigrelli et al. (1976). The presence of strains or sibling species of $I$. multifiliis was recently confirmed immunologicalìy by Dickerson et al. (1993). Since the water temperature at Site 3 in this study seldom drops below $19^{\circ} \mathrm{C}$ in winter, it is possible that the C. irritans isolated from the fish from Site 3 has different temperature tolerances than the isolates from Sites 1 and 2. Preliminary studies in our laboratory also indicate that there may be some significance in the fact that tomonts collected from Sites 1 and 2 showed variation in diameter with host species, whilst those from Site 3 did not.

From our study of infections of Acanthopagrus australis from Sites 1 and 2 it was clear the diameter of tomonts was not influenced by fish size, but varied inversely with water temperature. A similar relationship between water temperature and parasite size has been found in fish experimentally infected with this isolate of Cryptocaryon irritans (Diggles \& Lester 1996), and is well known for I. multifiliis (see MacLennan 1942, Wagner 1960). One advantage of producing larger tomonts at lower temperatures could be an increase in the number of infective stages, as this is directly related to tomont diameter (Colorni 1985, Diggles \& Lester 1996). However, theront size at lower temperatures is also larger (Diggles \& Lester 1996), so the increase in tomont size at lower temperatures in effect acts only to maintain the overall number of larger infective stages. Why $C$. irritans theronts are larger at lower temperatures is not clear, but it has been hypothesised that larger infective stages may have greater reserves of energy to increase their period of infectivity at lower temperatures (Diggles \& Lester 1996)

In contrast to results of previous studies (Laird 1956, Leong \& Wong 1989, Bunkley-Williams \& Williams 1994), our results show that wild fish harbouring infections of Cryptocaryon irritans are quite common in the areas we surveyed. In previous studies researchers used conventional autopsy and wet smear techniques which appear not to be effective for detecting the low intensity $C$. irntans infections typical of wild fish. Indeed it would be virtually impossible to accurately estimate the intensity of the $C$. irritans infections found in this study if conventional dissection methods were used. Examining the aquarium bottom for tomonts appears a more sensitive technique, though the process of collecting tomonts, siphoning supernatants and decanting sediments can still result in some tomonts being overlooked. There is also a potential for overestimation if water temperatures are not carefully monitored to ensure that tomonts are detected and removed before they excyst and reinfect fish. Preexperiment trials ensured that this did not occur in the present study, thius the data obtained in this survey may in some cases be slight underestimates of the intensity of wild infections, but in no instance are they overestimates. Another drawback of our method is that the researcher is restricted in the size and number of fish which can be examined at any one time (as in this study) by the size and number of aquaria which are available, but on the other hand, this nondestructive method of sampling for $C$. irritans allows the researcher to return the fish to the wild alive.

It is clear that Cryptocaryon irritans is common year round in the subtropical waters we sampled. Further application of our tomont collection technique may prove that this parasite is in fact abundant in tropical and subtropical waters throughout the world and is not rare as previously thought. In addition, it may be found that $C$. irritans exhibits a degree of host specificity in many areas where it occurs in the wild. Since we found infections to occur in water temperatures down to $15^{\circ} \mathrm{C}$, the distribution of $C$. irritans in the wild is effectively widened (at least seasonally) into warm temperate waters, and thus has important implications for temperate aquaculture in Australia and worldwide. We also found that $C$. irritans infects estuarine fish, thus extending its known range into estuaries as well as open waters.

Acknowledgements. We thank E. Boel, M. Bryant, N. Diggles, S. Chapman, I. Ernst and S. Wesche for helping in field collections, and the staff and management at Heron Island Research Station and The Port of Brisbane Authority for allowing access to their facilities during sampling. This paper forms part of the doctoral thesis of B.K.D. and was supported by an AustraLian Postgraduate Research Award scholarship.

\section{LITERATURE CITED}

Blaber SJM, Blaber TG (1980) Factors affecting the distribution of juvenile estuarine and inshore fish. J Fish Biol 17: $143-162$

Brown EM (1951) A new parasitic protozoan, the causal organism of a white spot disease in marine fish Crypto- 
caryon irritans gen. \& sp.n. Agen Sci Meet Zool Soc Lond $195011: 1-2$

Bunkley-Williams L, Williams EH (1994) Diseases caused by Trichodina spheroidesi and Cryptocaryon irritans (Ciliophora) in wild coral reef fishes. J Aquat Anim Health 6: $360-361$

Burgess PJ, Matthews RA (1994a) A standardised method for the in vivo maintenance of Cryptocaryon irritans (Ciliophora) using the grey mullet Chelon labrosus as an experimental host. J Parasitol 80:288-292

Burgess PJ, Matthews RA (1994b) Cryptocaryon irritans (Ciliophora): photoperiod and transmission in marine fish. J Mar Biol Ass UK 74:535-542

Burgess PJ, Matthews RA (1995) Fish host range of seven isolates of Cryptocaryon irritans (Ciliophora). J Fish Biol 46: $727-729$

Cheung PJ, Nigrelli RF, Ruggieri GD (1979) Studies of cryptocaryoniasis in marine fish: effect of temperature and salinity on the reproductive cycle of Cryptocaryon irritans Brown 1951. J Fish Dis 2:93-97

Colorni A (1985) Aspects of the biology of Cryptocaryon irritans, and hyposalinity as a control measure in cultured gilt-head sea bream Sparus aurata. Dis Aquat Org 1:19-22

Colorni A (1987) Biology of Cryptocaryon irritans and strategies for its control. Aquaculture 67:236-237

Diamant A, Issar G, Colorni A, Paperna I (1991) A pathogenic Cryptocaryon-like ciliate from the Mediterranean Sea. Bull Eur Ass Fish Pathol 11:122-124

Dickerson HW, Clark TG, Leff AA (1993) Serotypic variation among isolates of Ichthyophthirius multifilis based on immobilisation. J Eukaryot Microbiol 40:816-820

Diggles BK, Lester RJG (1996) Influence of temperature and host species on the development of Cryptocaryon irritans. J Parasitol 82:45-52

Grant EM (1985) Guide to fishes. Department of Harbours and Marine, Brisbane

Huff JA, Burns CD (1981) Hyper saline and chemical control of Cryptocaryon irritans in red snapper, Lutjanus campechanus monoculture. Aquaculture 22:181-184

Kaige N, Miyazaki T (1985) A histopathological study of white spot disease in Japanese flounder. Fish Pathol 20:61-64 (in Japanese, English summary)

Responsible Subject Editor: W. Körting, Hannover, Germany
Kearn GC (1986) Role of chemical substances from fish hosts in hatching and host-finding in monogeneans. I Chem Ecol 12:1651-1658

Laird M (1956) Aspects of fish parasitology. Proc 2nd Joint Symp Sci Soc Malaya Malayan Math Soc 46-54

Leong T, Wong S (1989) Parasites of wild and cultured golden snapper, Lutjanus johni (Bloch), in Malaysia. Tropic Biomed $6: 73-76$

Lom J, Cerkasovová A (1974) Host finding in invasive stages of IChthyophthirius multifilivs. J Protozool 21:457

MacLennan RF (1942) Growth in the ciliate Ichthyophthirius II. Volume. J Exp Zool 91:1-13

Nigrelli RF, Pokorny KS, Ruggieri GD (1976) Notes on Ichthyophthirius multifiliis, a ciliate parasitic on freshwater fishes, with some remarks on possible physiological races and species. Trans Am Microsc Soc 95:607-613

Nigrelli RF, Ruggieri GD (1966) Enzootics in the New York Aquarium caused by Cryptocaryon irntans Brown, 1951 (= Ichthyophthinus marinus Sikama, 1961), a histophagous ciliate in the skin, eyes and gills of marine fishes. Zoologica 51:97-102

Pollock B (1982) Spawning period and growth of yellowfin bream Acanthopagrus australis (Günther), in Moreton Bay, Australia. J Fish Biol 21:349--355

Randall JE, Allen GR, Steene RC (1990) Fishes of the Great Barier Reef and Coral Sea. Crawford House Press, Bathurst, NSW

Rasheed VM (1989) Diseases of cultured brown-spotted grouper Epinephelus tauvina and silvery black porgy Acanthopagrus cuvieri in Kuwait. J Aquat Anim Health 1. $102-107$

Sikama Y (1961) On a new species of Ichthyophthirius found in marine fishes. Sci Rep Yokosuka City Mus 6:66-70

Wagner G (1960) Der Entwicklungszyklus von Ichthyophthirius multifiliis Fouquet und der Einfluß physikalischer und chemischer Außenfaktoren. Z Fisch 9:425-443

Wilkie DW, Gordin H (1969) Outbreak of cryptocaryoniasis in marine aquaria at Scripps Institution of Oceanography. Calif Fish Game 55:227-236

Yoshinaga T, Dickerson HW (1994) Laboratory propagation of Cryptocaryon irritans on a saltwater-adapted Poecilia hybrid, the black molly. J Aquat Anim Health 6:197-201

Manuscript first received: July 28, 1995

Revised version accepted: November 29, 1995 